\title{
Nitrate-driven urban haze pollution during summertime over the North China Plain
}

\section{Haiyan Li et al.}

Correspondence to: Qiang Zhang (qiangzhang@ @tsinghua.edu.cn) and Kebin He (hekb@tsinghua.edu.cn)

The copyright of individual parts of the supplement might differ from the CC BY 4.0 License. 
Text S1. Positive matrix factorization of organic aerosol

20 Positive matrix factorization (PMF) analysis was performed for 1 to 8 factors with the rotational

21 parameter $($ FPEAK) varying from -1 to 1 (step $=0.2)$ for both the Beijing and Xinxiang 22 measurements. Detailed information on how to select the PMF factors can be found in Tables S1232 and Figs. S2-7. Finally, a four-factor solution with FPEAK $=0$ and a three-factor solution with 24 FPEAK $=0$ were chosen as the optimal solutions for Beijing and Xinxiang, respectively. The mass 25 spectra, time series, diurnal variations, and correlations with external tracers of the organic aerosol 26 (OA) factors are evaluated in Figs. S2-7. 
28 Table S1. Detailed investigation of the PMF solutions of the Beijing measurements.

\begin{tabular}{|c|c|c|c|}
\hline $\begin{array}{l}\text { Factor } \\
\text { number }\end{array}$ & FPEAK & $\mathrm{Q} / \mathrm{Q}_{\exp }$ & Solution Description \\
\hline 1 & 0 & 1.11 & $\begin{array}{l}\text { Too few factors, large residuals at time periods and } \\
\text { key } \mathrm{m} / \mathrm{z} \text { 's }\end{array}$ \\
\hline 2 & 0 & 0.73 & $\begin{array}{l}\text { Too few factors, large residuals at time periods and } \\
\text { key } \mathrm{m} / \mathrm{z} \text { 's }\end{array}$ \\
\hline 3 & 0 & 0.69 & $\begin{array}{l}\text { Too few factors (mixed HOA and COA, SV-OOA, } \\
\text { and LV-OOA). Factors are mixed to some extent } \\
\text { based on the time series and spectra. }\end{array}$ \\
\hline 4 & 0 & 0.67 & $\begin{array}{l}\text { Optimum choices for PMF factors (HOA, COA, } \\
\text { SV-OOA, and LV-OOA). Time series and diurnal } \\
\text { variations of the PMF factors are consistent with } \\
\text { the external tracers. The spectra of the four factors } \\
\text { are consistent with the source spectra in the AMS } \\
\text { spectra database. }\end{array}$ \\
\hline $5-8$ & 0 & $0.65-0.61$ & $\begin{array}{l}\text { Factor split. For example, when factor num. }=5 \text {, HOA } \\
\text { was split into two factors with similar spectra but } \\
\text { different time series. When factor num. }=6 \text {, there is } \\
\text { an extra split factor from SV-OOA. }\end{array}$ \\
\hline
\end{tabular}


31 Table S2. Detailed investigation of the PMF solutions of the Xinxiang measurements.

\begin{tabular}{|c|c|c|c|}
\hline $\begin{array}{l}\text { Factor } \\
\text { number }\end{array}$ & FPEAK & $\mathrm{Q} / \mathrm{Q}_{\exp }$ & Solution Description \\
\hline 1 & 0 & 1.24 & $\begin{array}{l}\text { Too few factors, large residuals at time periods and } \\
\text { key } m / z \text { 's }\end{array}$ \\
\hline 2 & 0 & 1.02 & $\begin{array}{l}\text { Too few factors (mixed HOA and SV-OOA, and LV- } \\
\text { OOA). Factors are mixed to some extent based on the } \\
\text { time series and spectra. }\end{array}$ \\
\hline 3 & 0 & 0.95 & $\begin{array}{l}\text { Optimum choices for PMF factors (HOA, SV- } \\
\text { OOA, and LV-OOA). Time series and diurnal } \\
\text { variations of the PMF factors are consistent with } \\
\text { the external tracers. The spectra of the three } \\
\text { factors are consistent with the source spectra in the } \\
\text { AMS spectra database. }\end{array}$ \\
\hline $4-8$ & 0 & $0.84-0.92$ & $\begin{array}{l}\text { Factor split. For example, when factor num. }=5 \text {, HOA } \\
\text { was split into two factors with similar spectra but } \\
\text { different time series. When factor num. }=6 \text {, there is } \\
\text { an extra split factor from SV-OOA. }\end{array}$ \\
\hline
\end{tabular}


Table S3-1. Summary of the location, sampling period, and references of field measurements during summertime discussed in this study.

\begin{tabular}{|c|c|c|c|}
\hline Dataset Name & Site type & Sampling period & References \\
\hline Beijing, 2006 & urban & $7 / 9 / 2006-7 / 21 / 2006$ & Sun et al. (2010) \\
\hline Beijing, 2008 & urban & 7/24/2008-9/20/2008 & Huang et al. (2010) \\
\hline Beijing, 2011 & urban & $6 / 26 / 2011-8 / 28 / 2011$ & Sun et al. (2012) \\
\hline Beijing, 2012 & urban & 7/29/2012-8/29/2012 & Hu et al. (2017) \\
\hline Beijing, 2015 & urban & $6 / 30 / 2015-7 / 27 / 2015$ & this study \\
\hline Beijing, China & rural/remote & $8 / 10 / 2006-9 / 9 / 2006$ & Gunthe et al. (2011) \\
\hline Xinxiang, China & urban & $8 / 8 / 2017-8 / 25 / 2017$ & this study \\
\hline Xinzhou, China & urban downwind & 7/17/2014-9/5/2014 & Wang et al. (2016) \\
\hline Xianghe, China & urban downwind & 6/1/2013-6/30/2013 & Sun et al. (2016) \\
\hline Nanjing, China & urban & 6/1/2013-6/15/2013 & Zhang et al. (2015) \\
\hline Shanghai, China & urban & $5 / 15 / 2010-6 / 10 / 2010$ & Huang et al. (2012) \\
\hline Jiaxing, China & urban downwind & $6 / 29 / 2010-7 / 15 / 2010$ & Huang et al. (2013) \\
\hline Back Garden, China & rural/remote & 7/12/2006-7/30/2006 & Xiao et al. (2011) \\
\hline Hongkong, China & urban downwind & $9 / 1 / 2011-9 / 29 / 2011$ & Li et al. (2015) \\
\hline Tokyo, Japan, 2003 & urban & $7 / 24 / 2003-8 / 13 / 2003$ & Takegawa, et al. (2006) \\
\hline Tokyo, Japan, 2004 & urban & $7 / 26 / 2004-8 / 15 / 2004$ & Miyakawa et al. (2008) \\
\hline Tokyo, Japan, 2008 & urban & $7 / 28 / 2008-8 / 29 / 2008$ & Xing et al. (2011) \\
\hline Wakayama, Japan & rural/remote & $8 / 20 / 2010-8 / 30 / 2010$ & Han et al. (2014) \\
\hline Gwangju, Korea & urban & $7 / 23 / 2012-8 / 6 / 2012$ & Park et al. (2013) \\
\hline BNL, NY & rural/remote & $7 / 15 / 2011-8 / 15 / 2011$ & Zhou et al. (2016) \\
\hline
\end{tabular}




\begin{tabular}{llll}
\hline Queens, NY, 2001 & urban & $6 / 30 / 2001-8 / 5 / 2001$ & Drewnick et al., (2010) \\
Queens, NY, 2009 & urban & $7 / 13 / 2009-8 / 3 / 2009$ & Sun et al. (2011) \\
Pinnacle State Park, NY & rural/remote & $7 / 18 / 2004-8 / 6 / 2004$ & Bae et al. (2007) \\
Look Rock, TN & rural/remote & $6 / 1 / 2013-9 / 21 / 2013$ & Budisulistiorini et al. (2016) \\
Centreville, AL & rural/remote & $6 / 1 / 2013-7 / 15 / 2013$ & Xu et al. (2015) \\
Yorkville, GA & rural/remote & $6 / 26 / 2012-7 / 20 / 2012$ & Xu et al. (2015) \\
Atlanta, GA & urban & $6 / 20 / 2012-9 / 21 / 2012$ & Budisulistiorini et al. (2016) \\
Rocky Park, CO & rural/remote & $7 / 2 / 2010-8 / 31 / 2010$ & Schurman et al. (2015) \\
Sacramento, CA & urban downwind & $6 / 2 / 2010-6 / 28 / 2010$ & Setyan et al. (2012) \\
Riverside, CA & urban & $7 / 15 / 2005-8 / 15 / 2005$ & Docherty et al. (2011) \\
London, UK & urban downwind & $7 / 30 / 2003-8 / 6 / 2003$ & Cubison et al. (2006) \\
Paris, France & urban downwind & $7 / 1 / 2009-7 / 31 / 2009$ & Crippa et al. (2013) \\
Zurich, Switzerland & urban downwind & $7 / 14 / 2005-8 / 4 / 2005$ & Lanz et al. (2010) \\
Melpitz, Germany & rural/remote & $5 / 23 / 2008-6 / 9 / 2008$ & Poulain et al. (2011) \\
Prague, Czech Republic & urban downwind & $6 / 20 / 2012-7 / 31 / 2012$ & Kubelova et al. (2015) \\
Mt. Cimone, Italy & rural/remote & $6 / 11 / 2012-7 / 11 / 2012$ & Rinaldi et al. (2015) \\
Crete, Greece & rural/remote & $8 / 16 / 2012-9 / 31 / 2012$ & Bougiatioti et al. (2014) \\
Patras, Greece & urban downwind & $6 / 8 / 2012-6 / 27 / 2012$ & Kostenidou et al. (2015) \\
Athens, Greece & urban downwind & $7 / 12 / 2012-7 / 26 / 2012$ & Kostenidou et al. (2015) \\
Hyytiälä, Finland & rural/remote & $7 / 12 / 2012-8 / 12 / 2010$ & Corrigan et al. (2013) \\
\hline & & & \\
\hline
\end{tabular}


Table S3-2. Summary of the average mass concentrations of aerosol species in submicron particles during the summer observations 36 discussed in this study (unit: $\mu \mathrm{g} \mathrm{m}^{-3}$ ).

\begin{tabular}{|c|c|c|c|c|c|c|c|c|}
\hline Dataset Name & PM type & PM Conc. & Org Conc. & $\mathrm{SO}_{4}$ Conc. & $\mathrm{NO}_{3}$ Conc. & $\mathrm{NH}_{4}$ Conc. & Chl Conc. & BC Conc. \\
\hline Beijing, 2006 & $\mathrm{NR} \mathrm{PM}_{1}$ & 80.0 & 28.0 & 20.0 & 17.6 & 12.8 & 1.1 & \\
\hline Beijing, 2008 & $\mathrm{PM}_{1}$ & 63.1 & 23.9 & 16.8 & 10.0 & 10.0 & 0.5 & 1.9 \\
\hline Beijing, 2011 & NR-PM 1 & 50.0 & 20.0 & 9.0 & 12.5 & 8.0 & 0.5 & \\
\hline Beijing, 2012 & $\mathrm{PM}_{1}$ & 37.5 & 12.5 & 9.7 & 6.3 & 5.4 & 0.3 & 3.2 \\
\hline Beijing, 2015 & $\mathrm{PM}_{1}$ & 35.0 & 12.2 & 6.3 & 8.4 & 4.3 & 0.4 & 3.1 \\
\hline Beijing, China & NR-PM 1 & 26.2 & 9.8 & 7.8 & 2.7 & 5.2 & 0.5 & \\
\hline Xinxiang, China & $\mathrm{PM}_{1}$ & 64.2 & 18.0 & 14.4 & 16.5 & 12.2 & 0.6 & 2.3 \\
\hline Xinzhou, China & $\mathrm{PM}_{1}$ & 35.4 & 11.7 & 11.5 & 5.1 & 4.2 & 0.5 & 2.4 \\
\hline Xianghe, China & $\mathrm{PM}_{1}$ & 73.0 & 28.5 & 13.1 & 14.6 & 8.8 & 2.9 & 5.1 \\
\hline Nanjing, China & $\mathrm{PM}_{1}$ & 38.5 & 15.0 & 4.6 & 8.9 & 6.2 & 0.4 & 3.1 \\
\hline Shanghai, China & $\mathrm{PM}_{1}$ & 29.2 & 8.4 & 9.7 & 4.8 & 3.9 & 0.5 & 2.0 \\
\hline Jiaxing, China & $\mathrm{PM}_{1}$ & 32.9 & 10.6 & 5.9 & 8.3 & 4.1 & 1.0 & 3.0 \\
\hline Back Garden, China & NR-PM 1 & 30.0 & 13.2 & 11.4 & 1.5 & 3.6 & 0.3 & \\
\hline Hongkong, China & NR-PM 1 & 15.6 & 4.1 & 8.7 & 0.4 & 2.4 & 0.01 & \\
\hline Tokyo, Japan, 2003 & $\mathrm{NR}-\mathrm{PM}_{1}$ & 12.7 & 5.7 & 3.2 & 1.0 & 1.8 & 0.09 & \\
\hline Tokyo, Japan, 2004 & $\mathrm{PM}_{1}$ & 33.0 & 14.5 & 9.1 & 1.5 & 4.0 & 0.3 & 3.6 \\
\hline Tokyo, Japan, 2008 & NR-PM 1 & 10.6 & 5.6 & 3.4 & 0.2 & 1.4 & 0.05 & \\
\hline Wakayama, Japan & NR-PM 1 & 4.0 & 1.8 & 1.6 & 0.04 & 0.5 & 0.01 & \\
\hline Gwangju, Korea & NR-PM 1 & 8.7 & 4.9 & 2.4 & 0.4 & 0.9 & 0.06 & \\
\hline
\end{tabular}




\begin{tabular}{|c|c|c|c|c|c|c|c|c|}
\hline $\mathrm{BNL}, \mathrm{NY}$ & $\mathrm{PM}_{1}$ & 12.6 & 8.1 & 3.0 & 0.2 & 1.0 & 0.01 & 0.1 \\
\hline Queens, NY, 2001 & $\mathrm{NR}_{-} \mathrm{PM}_{1}$ & 10.6 & 2.7 & 3.9 & 0.8 & 1.4 & 0.03 & \\
\hline Queens, NY, 2009 & $\mathrm{PM}_{1}$ & 11.7 & 6.3 & 2.8 & 0.5 & 1.3 & 0.03 & 0.7 \\
\hline Pinnacle State Park, NY & NR-PM 1 & 12.3 & 5.7 & 4.9 & 0.4 & 1.3 & 0.01 & \\
\hline Look Rock, TN & NR-PM 1 & 8.4 & 5.3 & 2.1 & 0.3 & 0.7 & 0.01 & \\
\hline Centreville, AL & NR-PM 1 & 7.4 & 5.0 & 1.9 & 0.1 & 0.4 & 0.01 & \\
\hline Yorkville, GA & $\mathrm{NR}_{-} \mathrm{PM}_{1}$ & 16.1 & 11.2 & 3.5 & 0.3 & 1.1 & 0.03 & \\
\hline Atlanta, GA & NR-PM 1 & 8.8 & 6.1 & 1.5 & 0.4 & 0.7 & 0.01 & \\
\hline Rocky Park, CO & NR-PM 1 & 5.1 & 3.8 & 0.8 & 0.2 & 0.2 & 0.05 & \\
\hline Sacramento, CA & $\mathrm{PM}_{1}$ & 3.0 & 2.4 & 0.3 & 0.1 & 0.1 & 0.003 & 0.05 \\
\hline Riverside, CA & $\mathrm{PM}_{1}$ & 20.5 & 9.1 & 3.5 & 4.4 & 2.5 & 0.09 & 0.9 \\
\hline London, UK & $\mathrm{NR}_{-} \mathrm{PM}_{1}$ & 5.4 & 2.5 & 1.7 & 0.5 & 0.7 & 0.04 & \\
\hline Paris, France & $\mathrm{PM}_{1}$ & 4.5 & 2.2 & 1.3 & 0.2 & 0.3 & 0.02 & 0.6 \\
\hline Zurich, Switzerland & NR-PM 1 & 9.6 & 6.5 & 1.4 & 0.8 & 0.1 & & \\
\hline Melpitz, Germany & $\mathrm{PM}_{1}$ & 11.6 & 6.8 & 2.5 & 0.6 & 0.9 & 0.02 & 0.6 \\
\hline Prague, Czech Republic & NR-PM 1 & 8.3 & 4.2 & 2.0 & 0.8 & 1.2 & 0.1 & \\
\hline Mt. Cimone, Italy & $\mathrm{NR}-\mathrm{PM}_{1}$ & 4.5 & 2.8 & 0.9 & 0.3 & 0.4 & 0.05 & \\
\hline Crete, Greece & $\mathrm{PM}_{1}$ & 9.2 & 3.2 & 4.0 & 0.2 & 1.3 & & 0.6 \\
\hline Patras, Greece & $\mathrm{PM}_{1}$ & 8.6 & 3.8 & 3.3 & 0.1 & 0.9 & & 0.5 \\
\hline Athens, Greece & $\mathrm{PM}_{1}$ & 14.2 & 6.6 & 5.3 & 0.2 & 1.4 & & 0.7 \\
\hline Hyytiälä, Finland & $\mathrm{PM}_{1}$ & 6.7 & 4.4 & 1.3 & 0.2 & 0.4 & & 0.3 \\
\hline
\end{tabular}



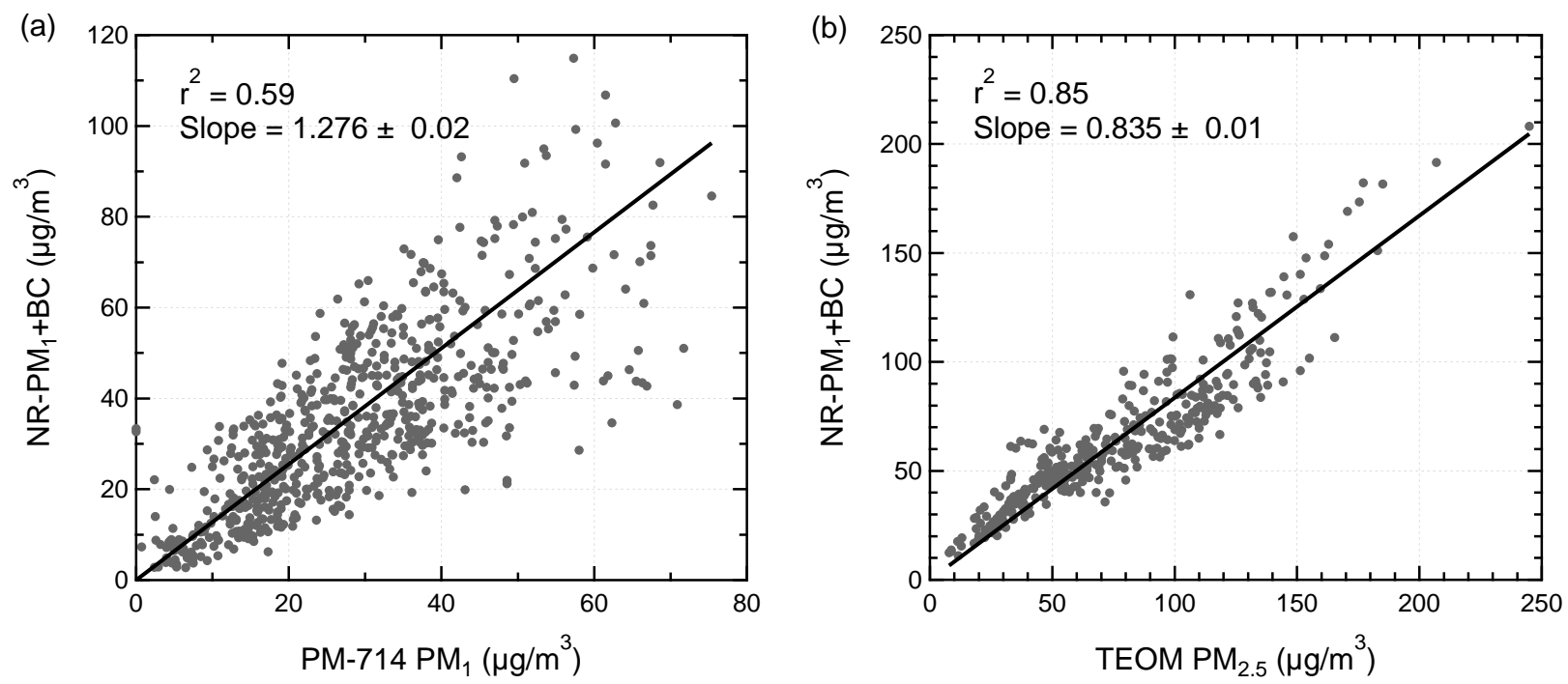

39 Figure S1. Scatter plots of (a) the mass concentrations of NR-PM 1 plus BC vs. total $\mathrm{PM}_{1}$ measured

40 by PM-714 in Beijing, and (b) the mass concentrations of NR-PM plus BC vs. total $\mathrm{PM}_{2.5}$ 41 measured by TEOM in Xinxiang. 

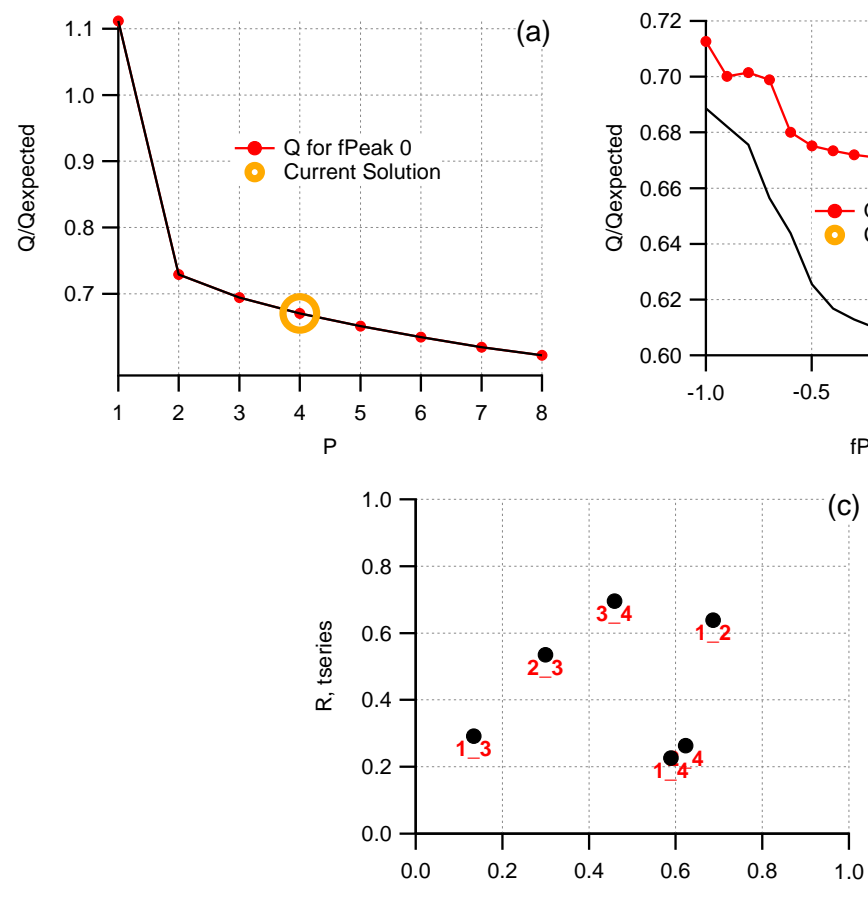

42
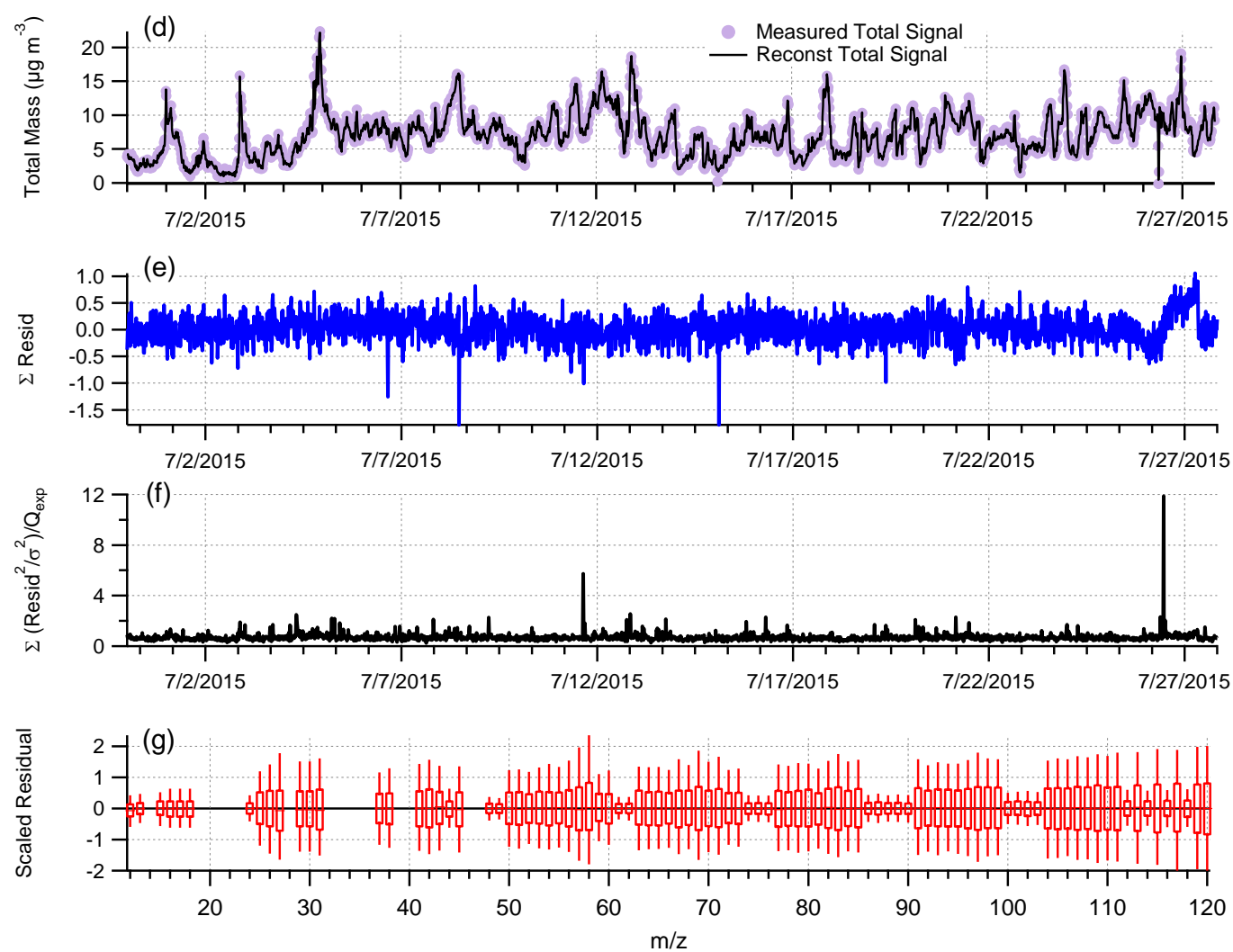

Figure S2. Summary of the key diagnostic plots of the chosen 4-factor solution from PMF analysis of the Beijing measurements. 

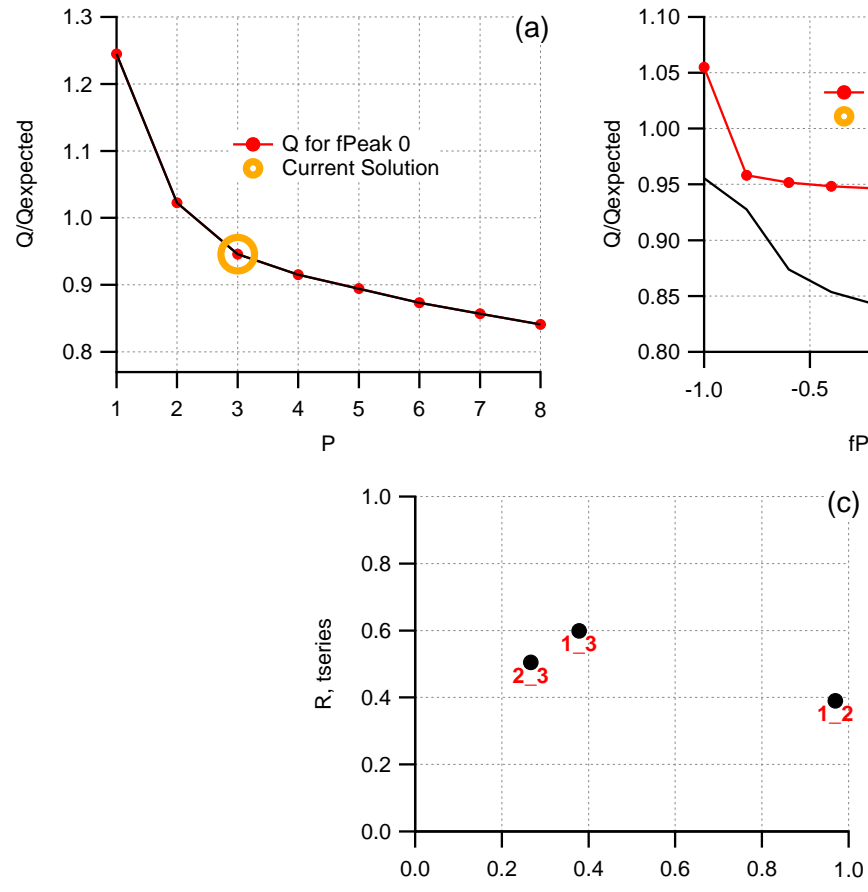

(b)

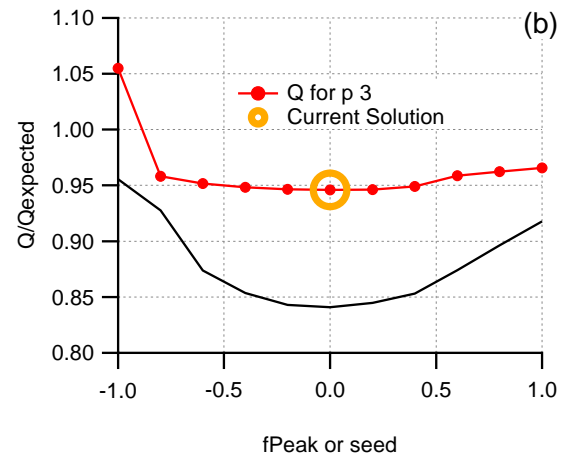

(c)
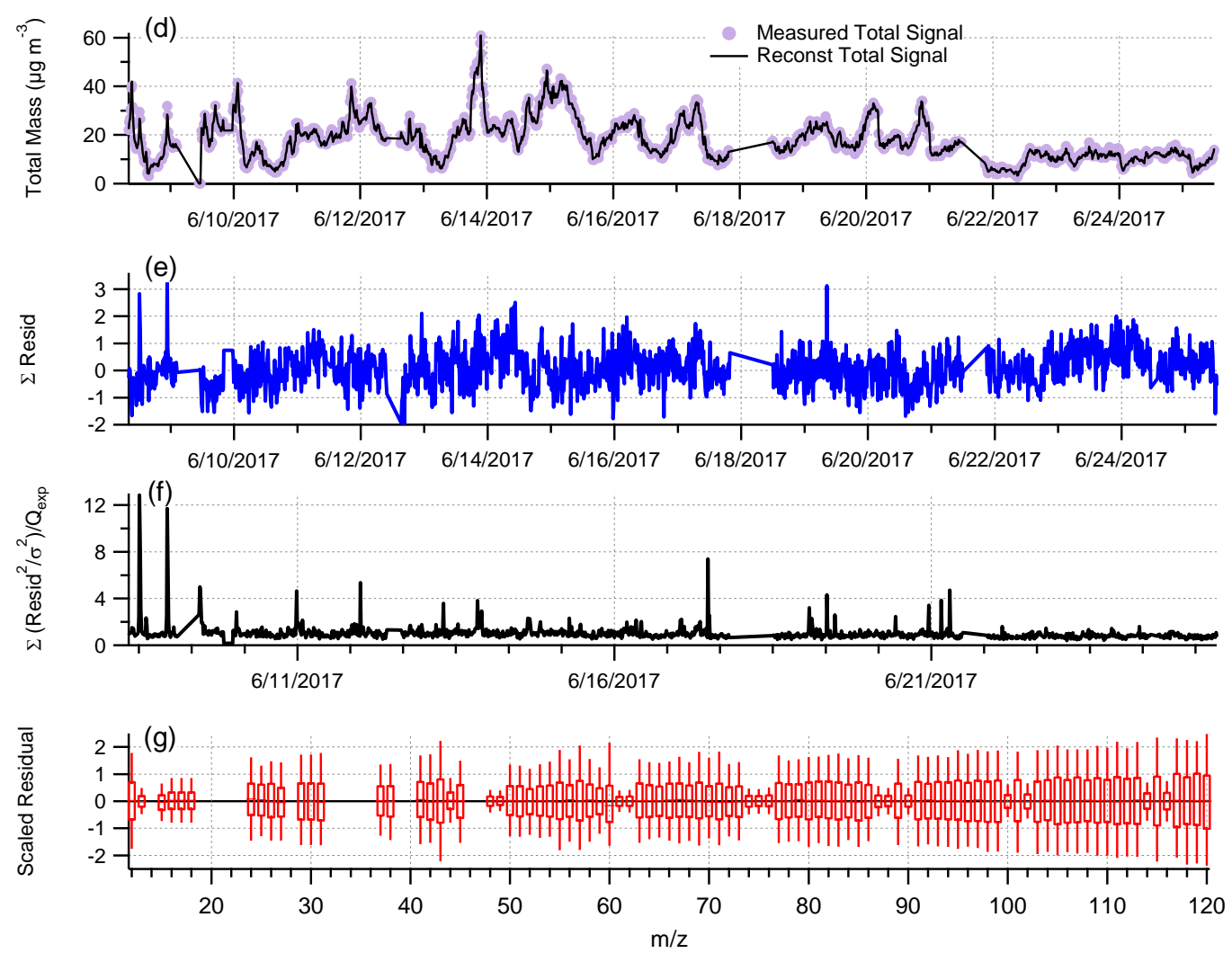

Figure S3. Summary of the key diagnostic plots of the chosen 3-factor solution from PMF analysis of the Xinxiang measurements. 
(a)
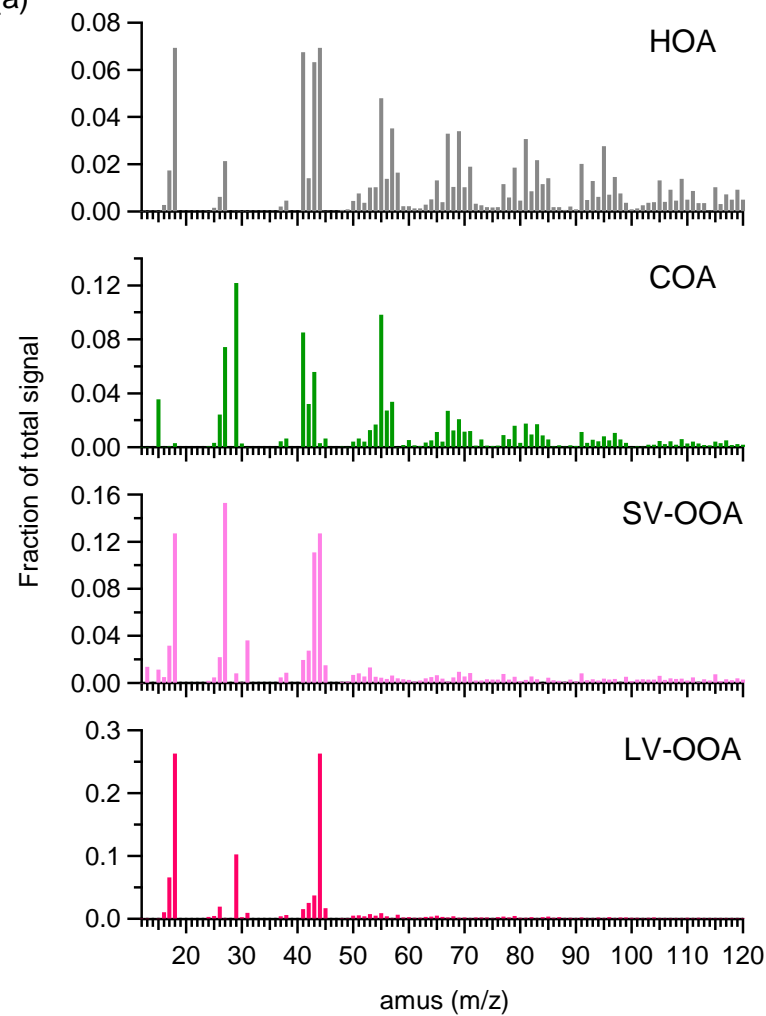

(c)

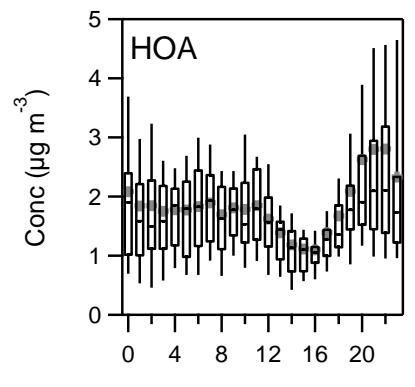

Hour of Day

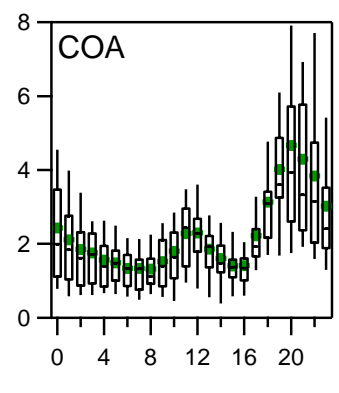

Hour of Day (b)
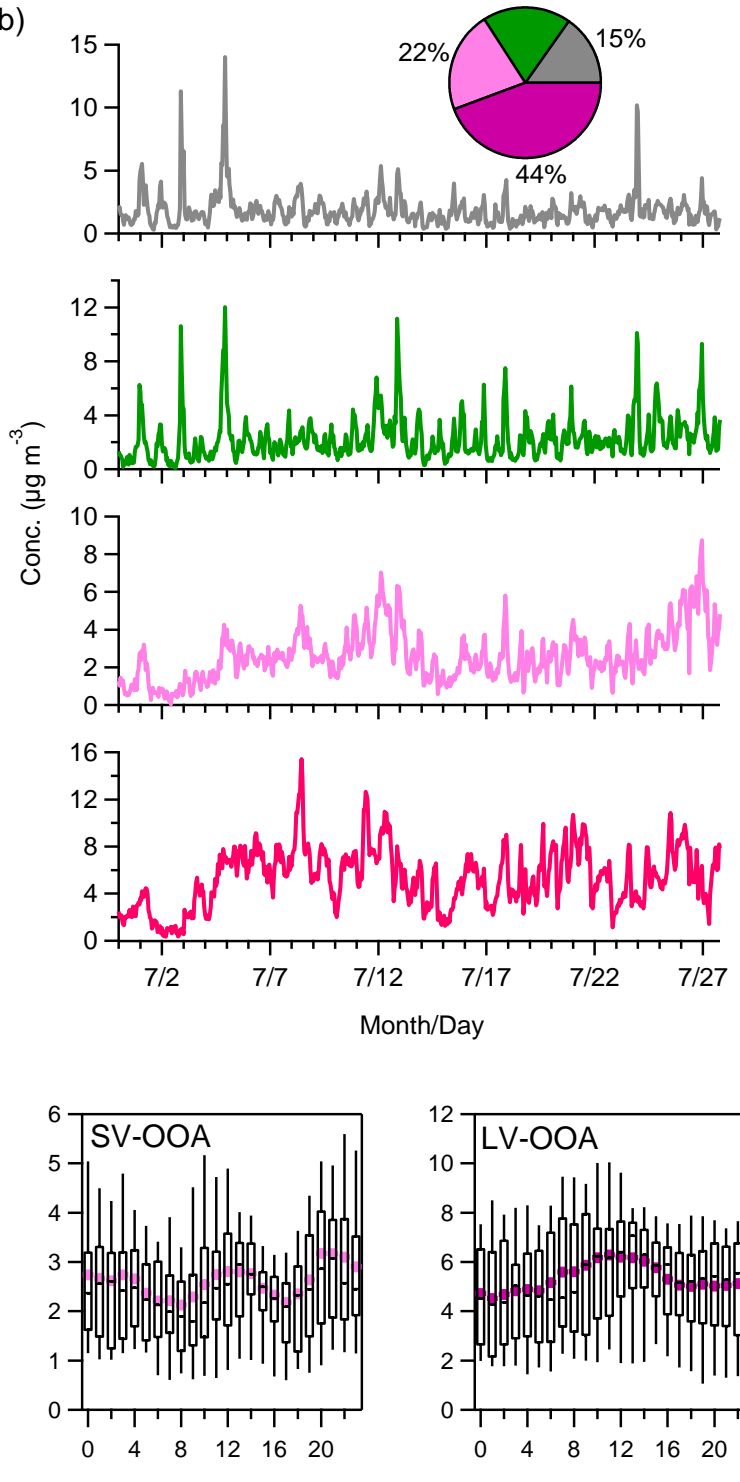

Hour of Day

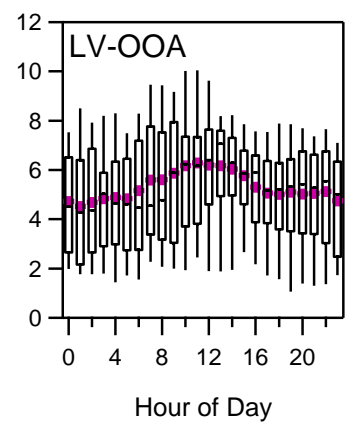

Hour of Day

52 Figure S4. (a) The mass spectra, (b) time series, and (c) diurnal variations of the four-factor PMF 53 solution of the Beijing measurements. 
(a)
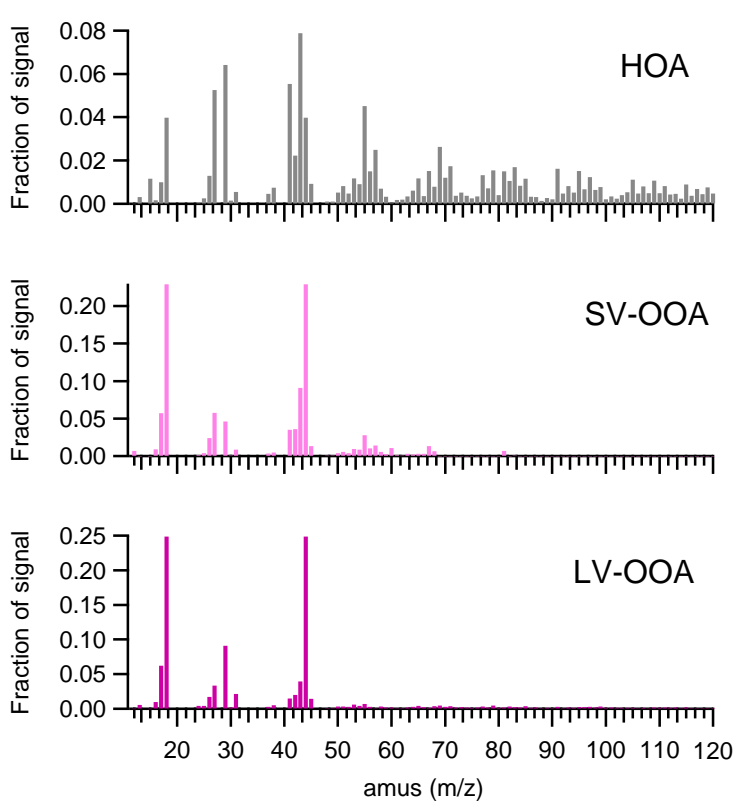

(c)

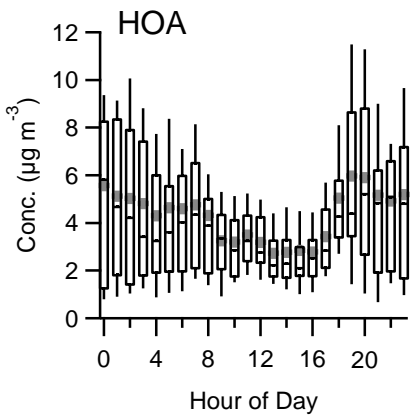

(b)
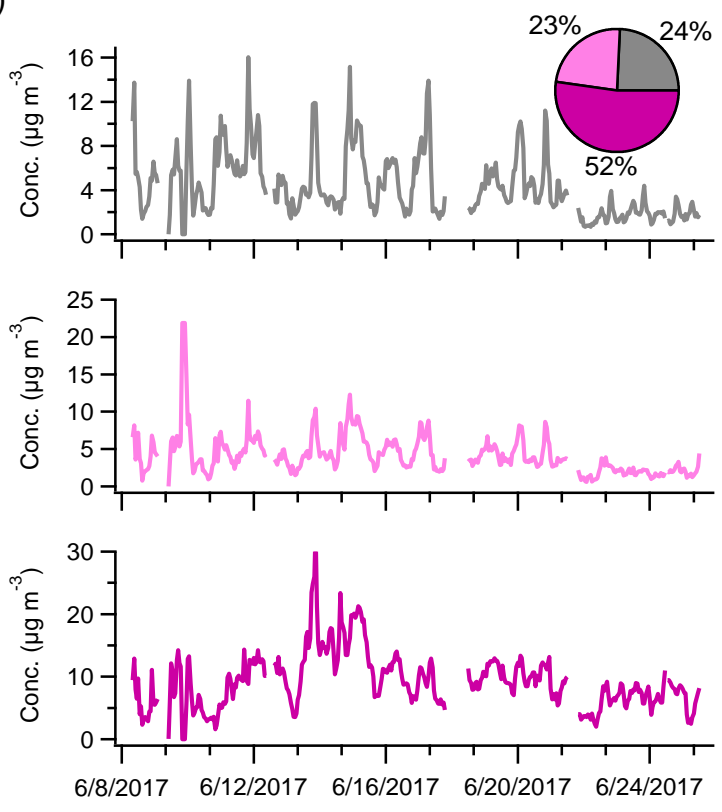
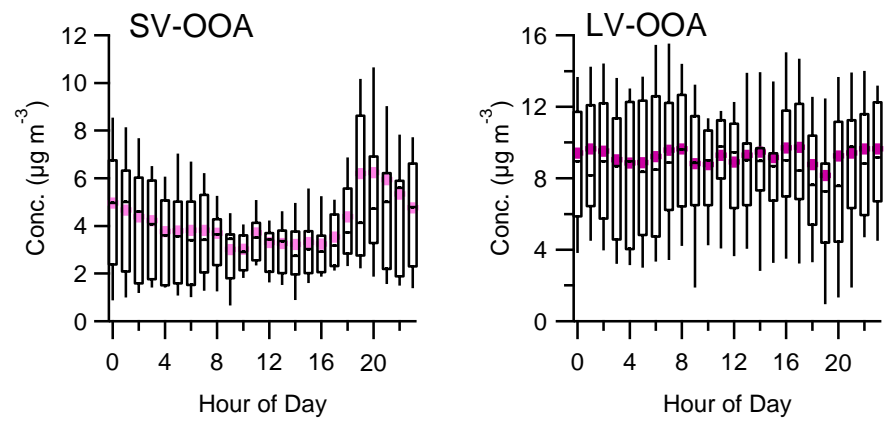

56 Figure S5. (a) The mass spectra, (b) time series, and (c) diurnal variations of the four-factor PMF 57 solution of the Xinxiang measurements. 

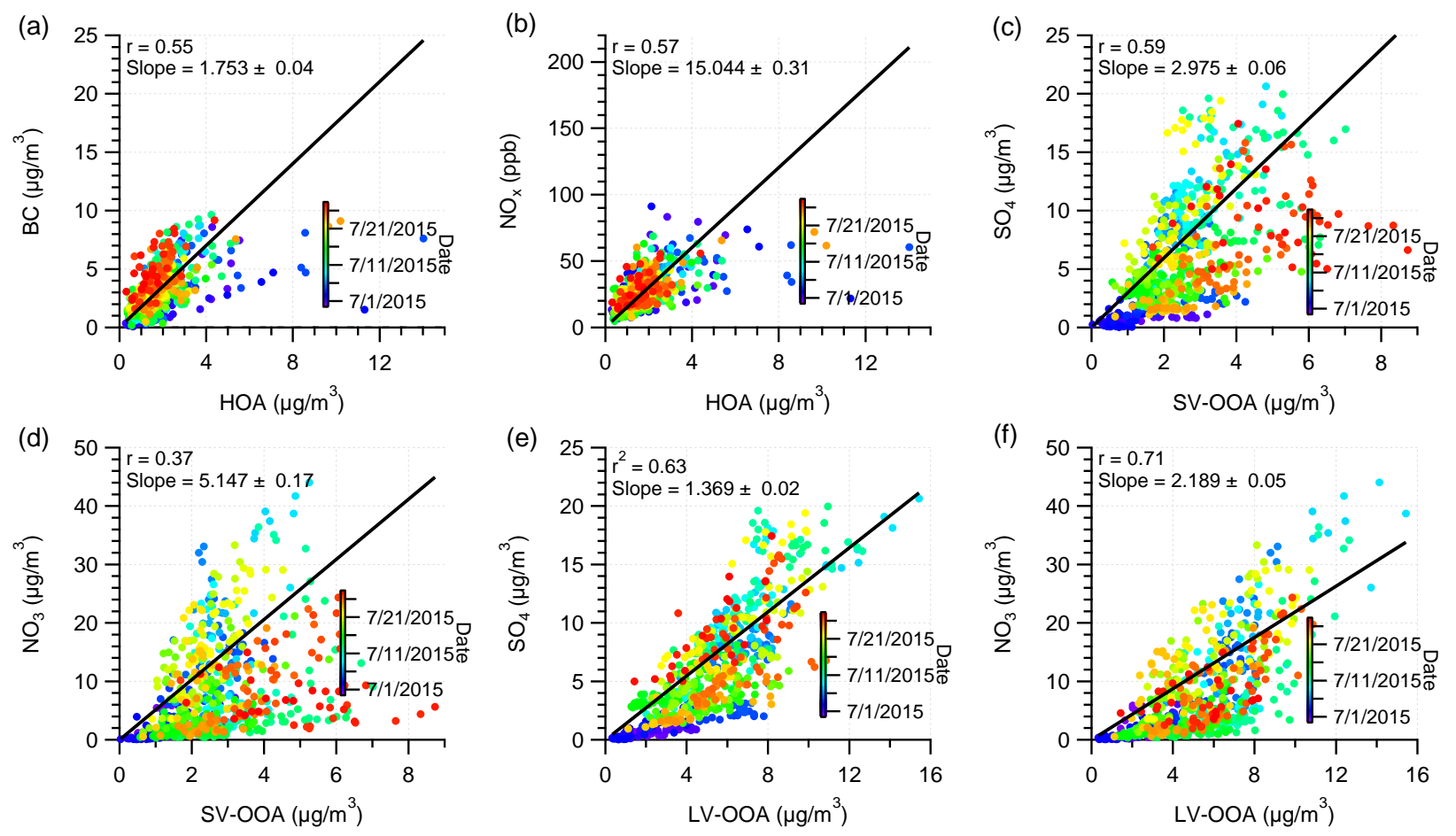

Figure S6. Scatter plots of (a) HOA vs. BC, (b) HOA vs $\mathrm{NO}_{x}$, (c) SV-OOA vs. sulfate, (d) SV-

61 OOA vs nitrate, (e) LV-OOA vs. sulfate, and (f) LV-OOA vs. nitrate of the Beijing measurements. 

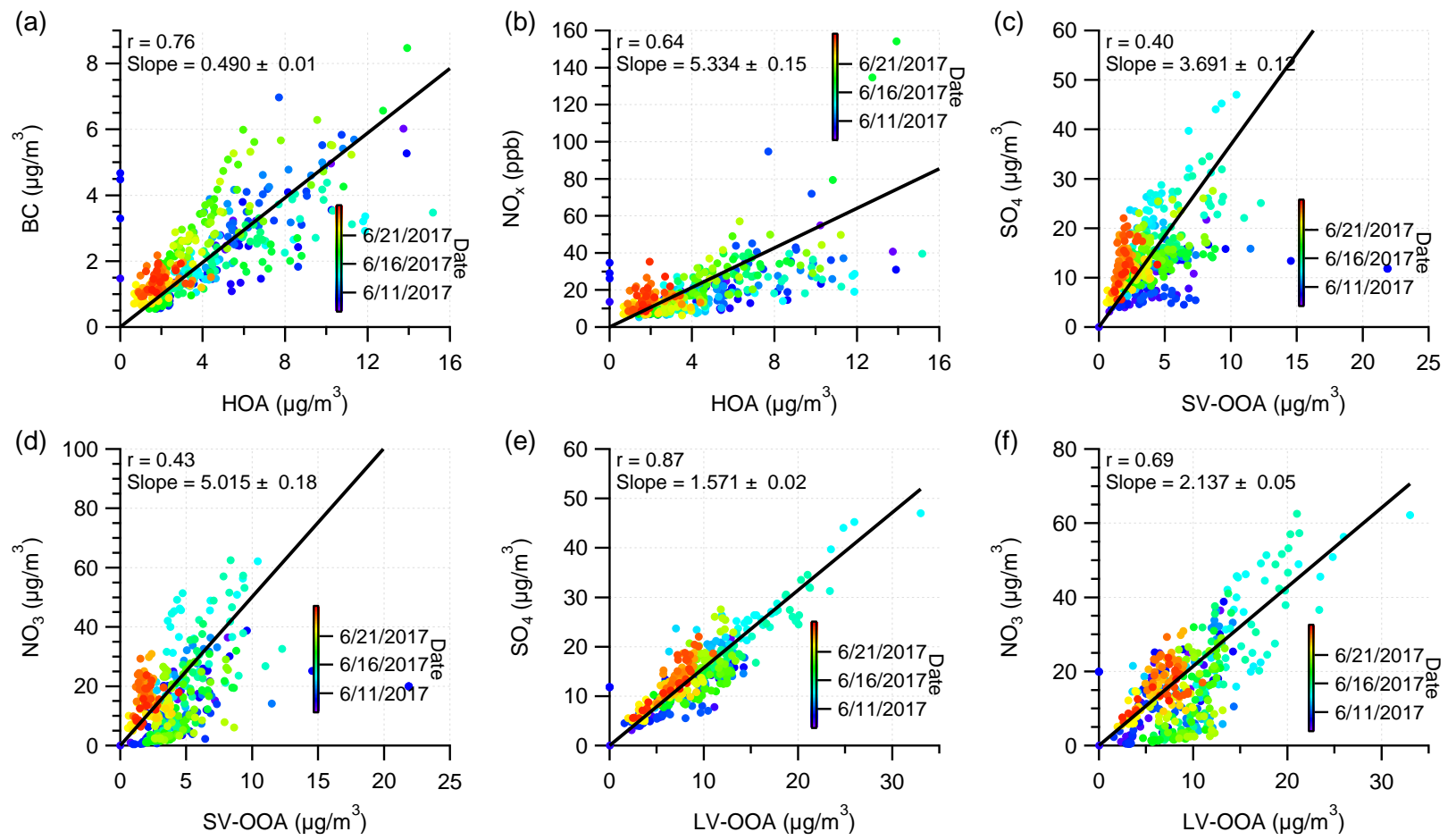

64 Figure S7. Scatter plots of (a) HOA vs. BC, (b) $\mathrm{HOA}_{\text {vs }} \mathrm{NO}_{\mathrm{x}}$, (c) SV-OOA vs. sulfate, (d) SV65 OOA vs nitrate, (e) LV-OOA vs. sulfate, and (f) LV-OOA vs. nitrate of the Xinxiang 66 measurements. 


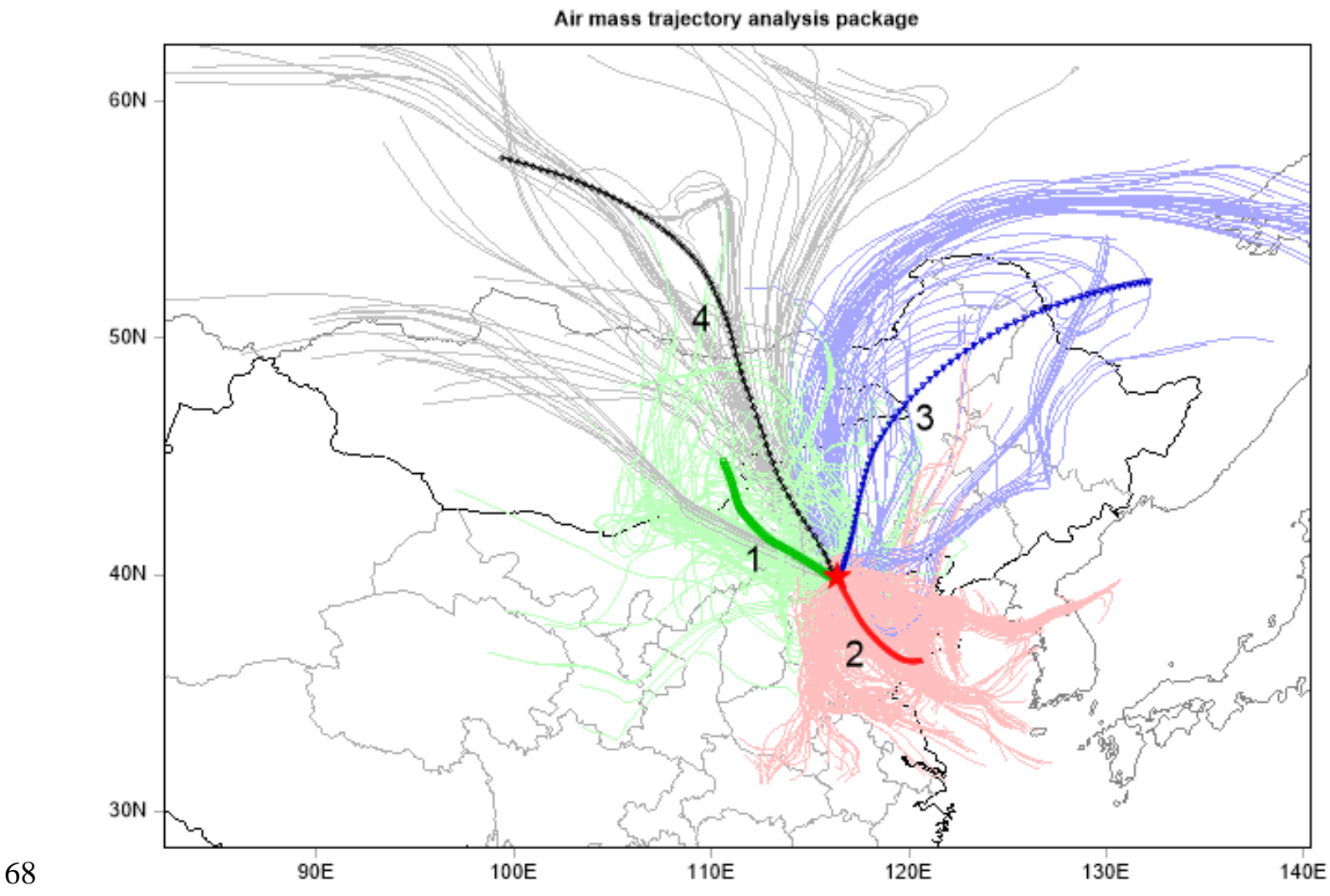

69 Figure S8. Back trajectories of air masses arriving in Beijing every hour, with the four clusters 70 determined using the inbuilt function in the HYSPLIT model. 
Beijing

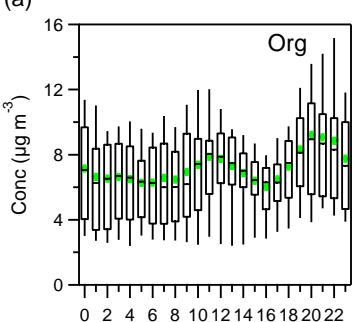

(c)
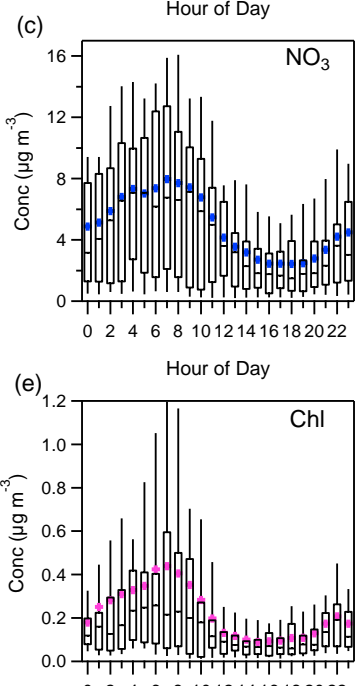

Hour of Day (b)
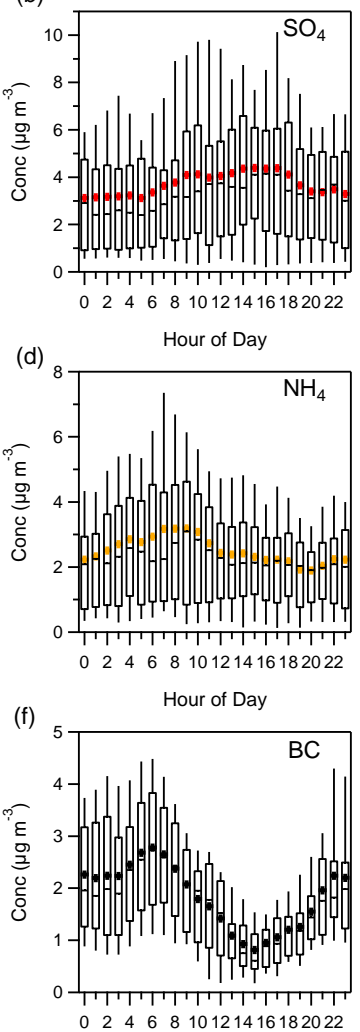

Hour of Day
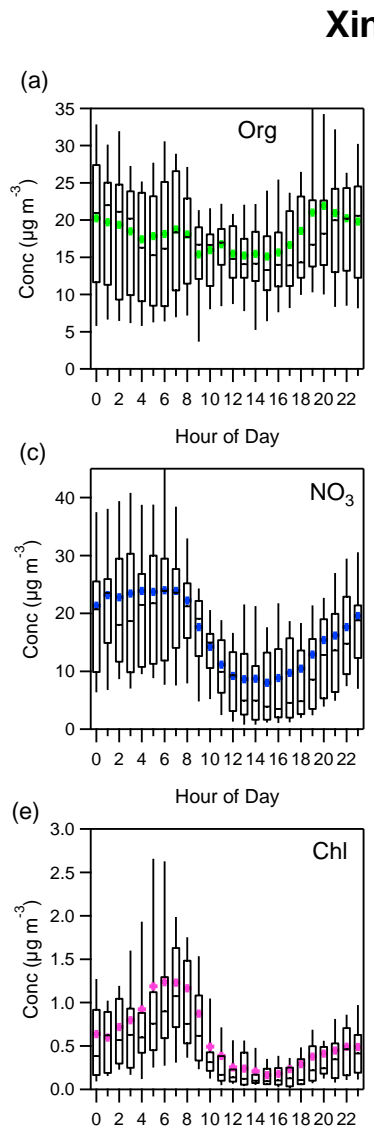

Hour of Day
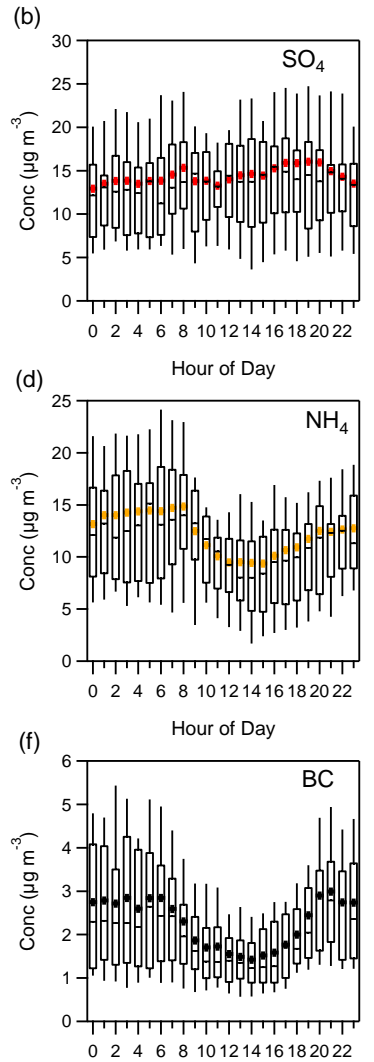

Hour of Day

73 Figure S9. Diurnal variations of (a) organics, (b) sulfate, (c) nitrate, (d) ammonium, (e) chloride, 74 and (f) BC in Beijing and Xinxiang. 

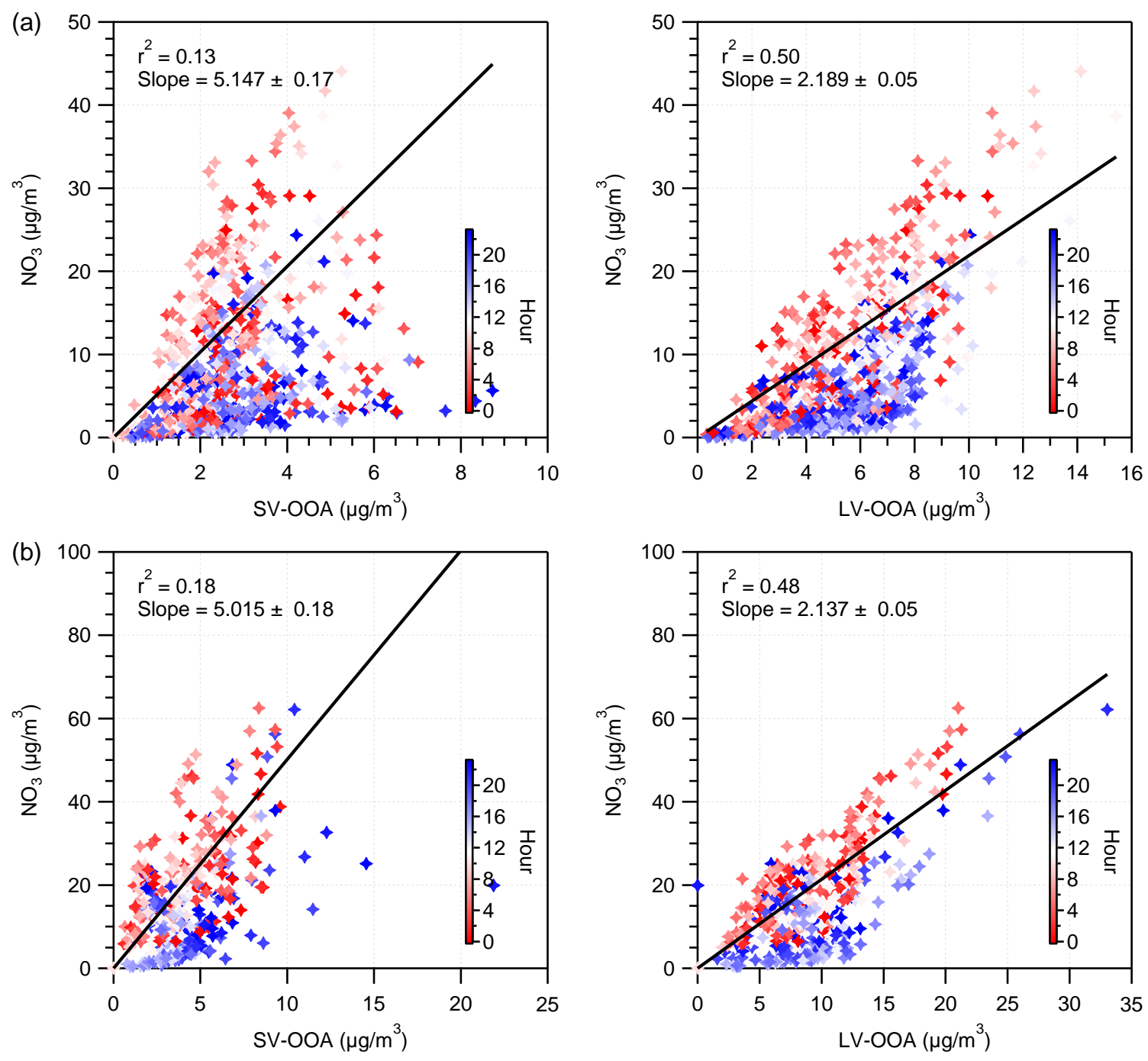

77 Figure S10. Scatterplots of nitrate vs. SV-OOA and nitrate vs. LV-OOA colored by the hour of 78 the day, in (a) Beijing and (b) Xinxiang. 

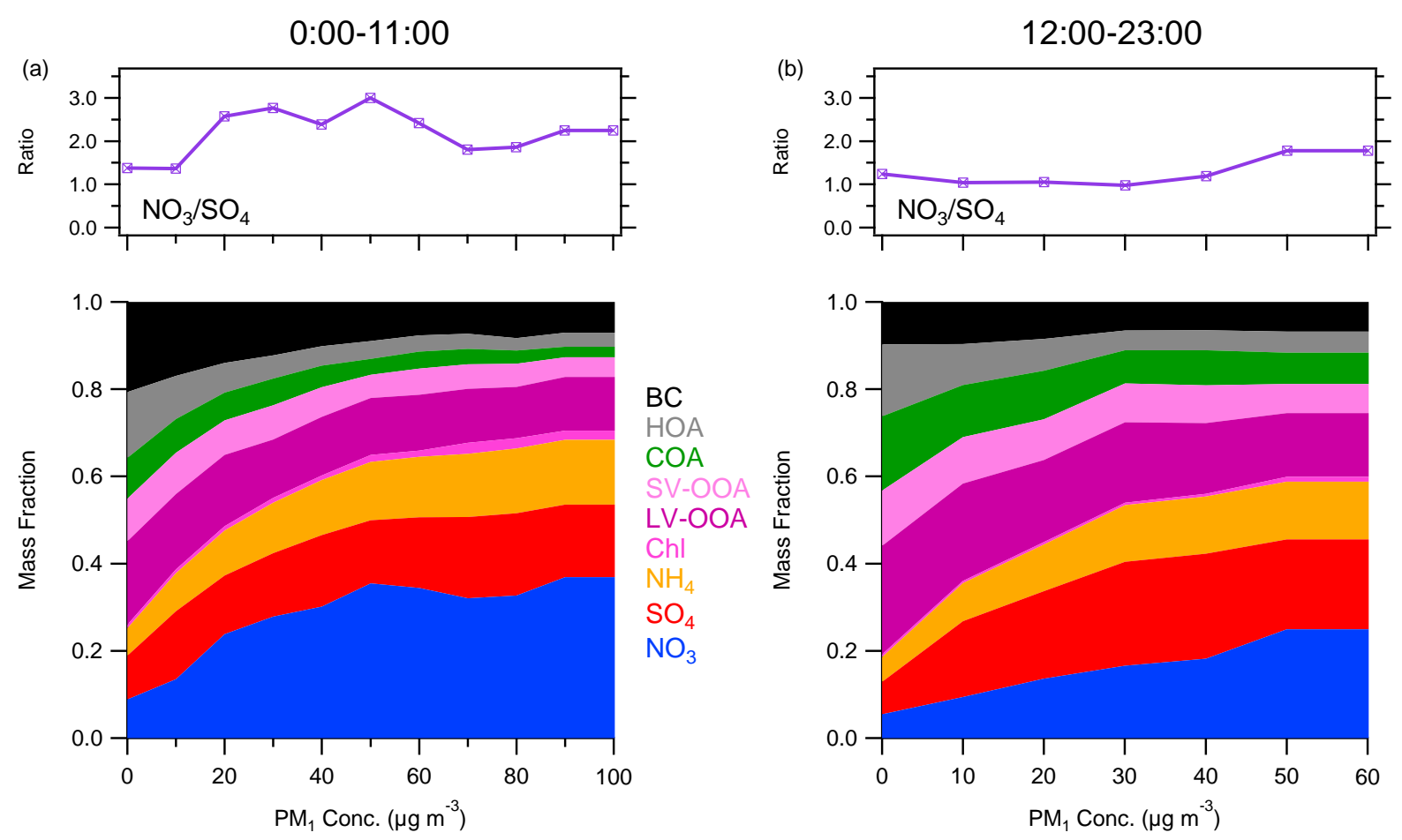

81 Figure S11. Variations in the mass fractions of aerosol species and nitrate/sulfate mass ratio as a 82 function of total $\mathrm{PM}_{1}$ mass loadings for the periods (a) 0:00 - 11:00 and (b) 12:00 -23:00 in Beijing. 


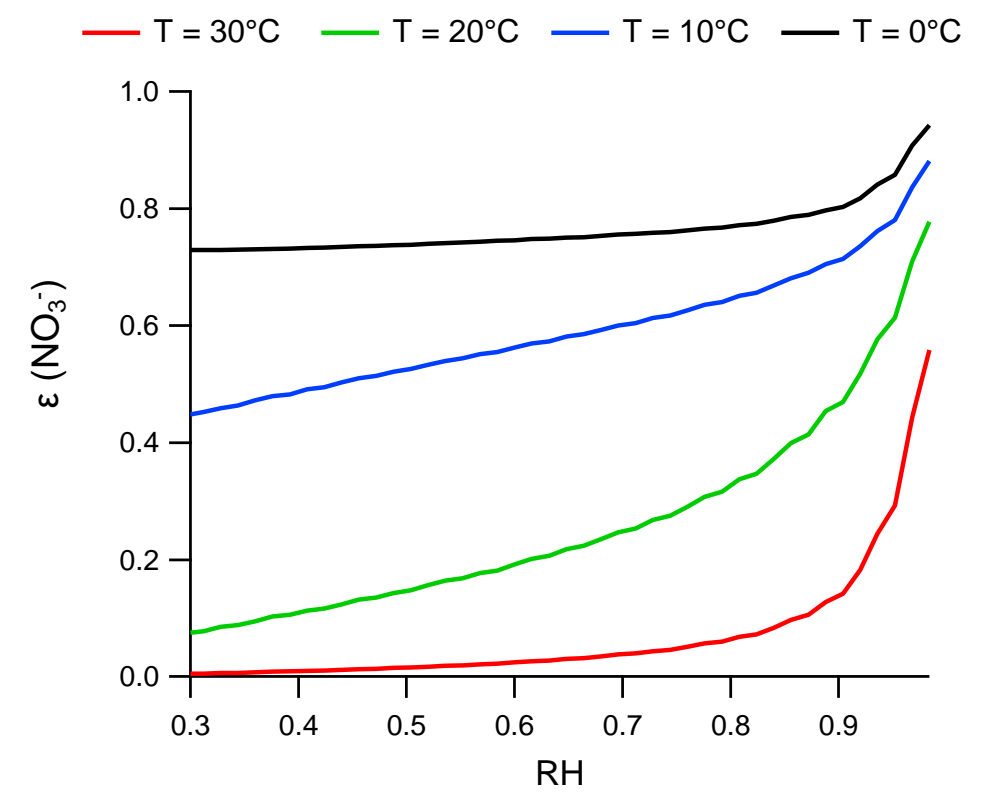

84

Figure S12. Simulated $\varepsilon\left(\mathrm{NO}_{3}^{-}\right)$by the ISORROPIA-II model at $0{ }^{\circ} \mathrm{C}, 10^{\circ} \mathrm{C}, 20^{\circ} \mathrm{C}$, and $30^{\circ} \mathrm{C}$ with 86 varying $\mathrm{RH}$ conditions.

87 


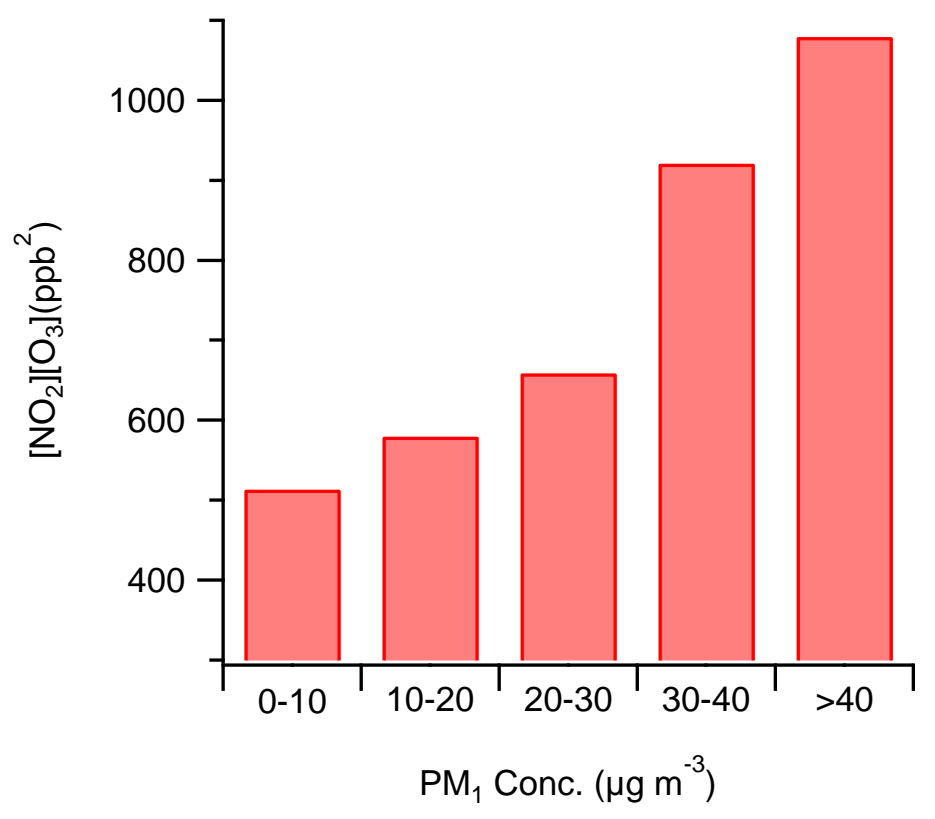

89 Figure S13. Variations in $\left[\mathrm{NO}_{2}\right]\left[\mathrm{O}_{3}\right]$ at 0:00 as a proxy for the nighttime formation of $\mathrm{HNO}_{3}$ for 90 different $\mathrm{PM}_{1}$ concentration bins. 


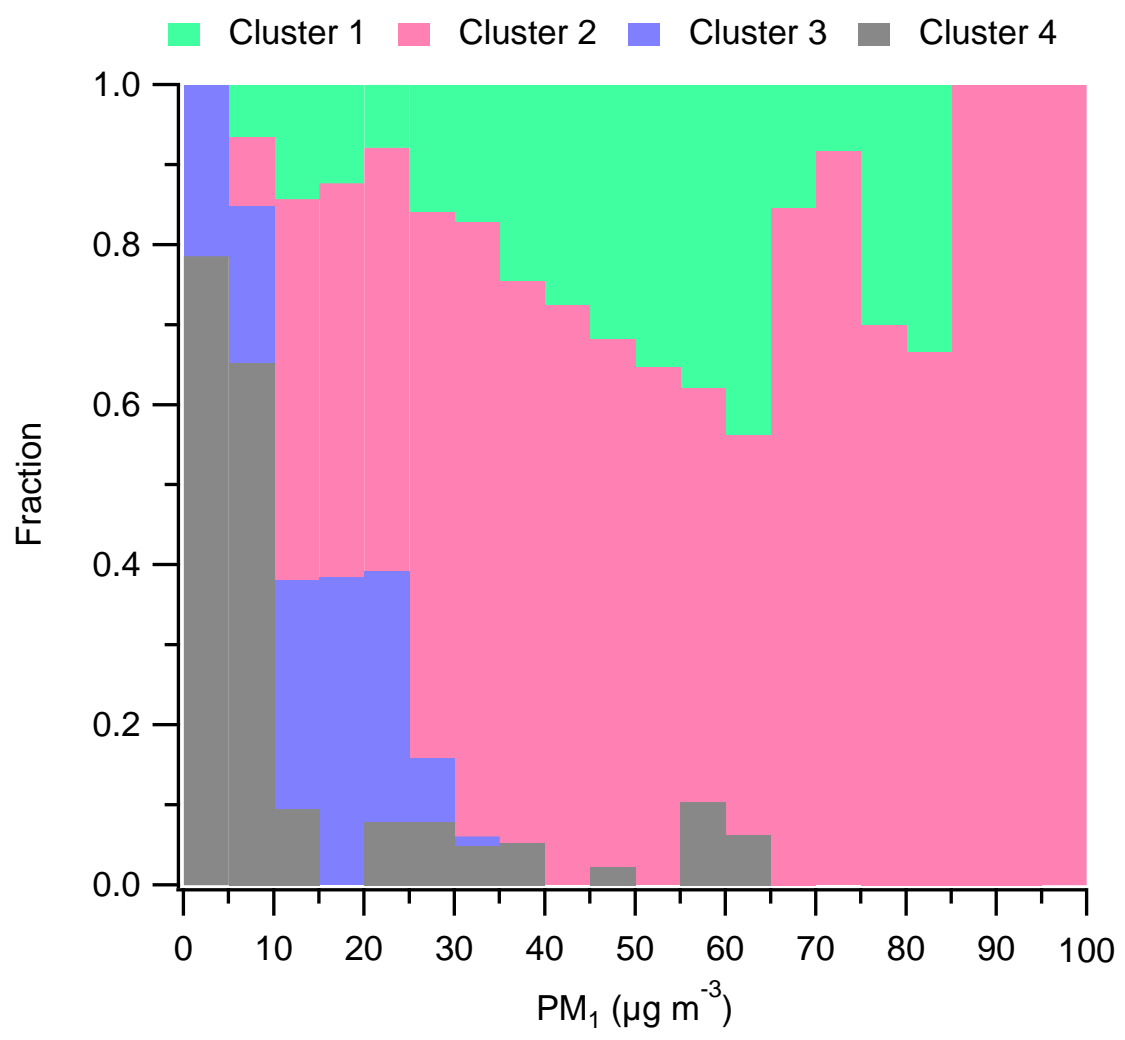

92 Figure S14. Distribution of the four clusters resolved in this study as a function of $\mathrm{PM}_{1}$ 93 concentration.

94 
Bae, M. S., Schwab, J. J., Zhang, Q., Hogrefe, O., Demerjian, K. L., Weimer, S., Rhoads, K., Orsini, D., Venkatachari, P., and Hopke, P. K.: Interference of organic signals in highly time resolved nitrate measurements by low mass resolution aerosol mass spectrometry, J Geophys Res-Atmos, 112, Artn D22305 10.1029/2007jd008614, 2007.

Bougiatioti, A., Stavroulas, I., Kostenidou, E., Zarmpas, P., Theodosi, C., Kouvarakis, G., Canonaco, F., Prévôt, A. S. H., Nenes, A., Pandis, S. N., and Mihalopoulos, N.: Processing of biomass-burning aerosol in the eastern Mediterranean during summertime, Atmos. Chem. Phys., 14, 4793-4807, https://doi.org/10.5194/acp-14-4793-2014, 2014.

Budisulistiorini, S. H., Baumann, K., Edgerton, E. S., Bairai, S. T., Mueller, S., Shaw, S. L., Knipping, E. M., Gold, A., and Surratt, J. D.: Seasonal characterization of submicron aerosol chemical composition and organic aerosol sources in the southeastern United States: Atlanta, Georgia, and Look Rock, Tennessee, Atmos. Chem. Phys., 16, 5171-5189, https://doi.org/10.5194/acp-16-5171-2016, 2016.

Corrigan, A. L., Russell, L. M., Takahama, S., Äijälä, M., Ehn, M., Junninen, H., Rinne, J., Petäjä, T., Kulmala, M., Vogel, A. L., Hoffmann, T., Ebben, C. J., Geiger, F. M., Chhabra, P., Seinfeld, J. H., Worsnop, D. R., Song, W., Auld, J., and Williams, J.: Biogenic and biomass burning organic aerosol in a boreal forest at Hyytiälä, Finland, during HUMPPA-COPEC 2010, Atmos. Chem. Phys., 13, 12233-12256, https://doi.org/10.5194/acp-13-12233-2013, 2013.

Crippa, M., El Haddad, I., Slowik, J. G., DeCarlo, P. F., Mohr, C., Heringa, M. F., Chirico, R., Marchand, N., Sciare, J., Baltensperger, U., and Prevot, A. S. H.: Identification of marine and continental aerosol sources in Paris using high resolution aerosol mass spectrometry, J Geophys Res-Atmos, 118, 1950-1963, 10.1002/jgrd.50151, 2013.

Cubison, M. J., Alfarra, M. R., Allan, J., Bower, K. N., Coe, H., McFiggans, G. B., Whitehead, J. D., Williams, P. I., Zhang, Q., Jimenez, J. L., Hopkins, J., and Lee, J.: The characterisation of pollution aerosol in a changing photochemical environment, Atmos. Chem. Phys., 6, 55735588, https://doi.org/10.5194/acp-6-5573-2006, 2006.

Docherty, K. S., Aiken, A. C., Huffman, J. A., Ulbrich, I. M., DeCarlo, P. F., Sueper, D., Worsnop, D. R., Snyder, D. C., Peltier, R. E., Weber, R. J., Grover, B. D., Eatough, D. J., Williams, B. J., Goldstein, A. H., Ziemann, P. J., and Jimenez, J. L.: The 2005 Study of Organic Aerosols at Riverside (SOAR-1): instrumental intercomparisons and fine particle composition, Atmos. Chem. Phys., 11, 12387-12420, https://doi.org/10.5194/acp-11-12387-2011, 2011.

Drewnick, F., Schwab, J. J., Jayne, J. T., Canagaratna, M., Worsnop, D. R., and Demerjian, K. L.: Measurement of ambient aerosol composition during the PMTACS-NY 2001 using an aerosol mass spectrometer. Part I: Mass concentrations, Aerosol Sci Tech, 38, 92-103, 10.1080/02786820390229507, 2004.

Gunthe, S. S., Rose, D., Su, H., Garland, R. M., Achtert, P., Nowak, A., Wiedensohler, A., Kuwata, M., Takegawa, N., Kondo, Y., Hu, M., Shao, M., Zhu, T., Andreae, M. O., and Pöschl, U.: Cloud condensation nuclei $(\mathrm{CCN})$ from fresh and aged air pollution in the megacity region of Beijing, Atmos. Chem. Phys., 11, 11023-11039, https://doi.org/10.5194/acp-11-110232011, 2011.

Han, Y. M., Iwamoto, Y., Nakayama, T., Kawamura, K., and Mochida, M.: Formation and evolution of biogenic secondary organic aerosol over a forest site in Japan, J Geophys ResAtmos, 119, 259-273, 10.1002/2013JD020390, 2014. 
Hu, W., Hu, M., Hu, W. W., Zheng, J., Chen, C., Wu, Y., and Guo, S.: Seasonal variations in high time-resolved chemical compositions, sources, and evolution of atmospheric submicron aerosols in the megacity Beijing, Atmos. Chem. Phys., 17, 9979-10000, 10.5194/acp-179979-2017, 2017.

Huang, X.-F., He, L.-Y., Hu, M., Canagaratna, M. R., Sun, Y., Zhang, Q., Zhu, T., Xue, L., Zeng, L.-W., Liu, X.-G., Zhang, Y.-H., Jayne, J. T., Ng, N. L., and Worsnop, D. R.: Highly timeresolved chemical characterization of atmospheric submicron particles during 2008 Beijing Olympic Games using an Aerodyne High-Resolution Aerosol Mass Spectrometer, Atmos. Chem. Phys., 10, 8933-8945, https://doi.org/10.5194/acp-10-8933-2010, 2010.

Huang, X. F., He, L. Y., Xue, L., Sun, T. L., Zeng, L. W., Gong, Z. H., Hu, M., and Zhu, T.: Highly time-resolved chemical characterization of atmospheric fine particles during 2010 Shanghai World Expo, Atmos Chem Phys, 12, 4897-4907, 10.5194/acp-12-4897-2012, 2012.

Huang, X. F., Xue, L., Tian, X. D., Shao, W. W., Sun, T. L., Gong, Z. H., Ju, W. W., Jiang, B., $\mathrm{Hu}, \mathrm{M}$., and He, L. Y.: Highly time-resolved carbonaceous aerosol characterization in Yangtze River Delta of China: Composition, mixing state and secondary formation, Atmos Environ, 64, 200-207, 10.1016/j.atmosenv.2012.09.059, 2013.

Kostenidou, E., Florou, K., Kaltsonoudis, C., Tsiflikiotou, M., Vratolis, S., Eleftheriadis, K., and Pandis, S. N.: Sources and chemical characterization of organic aerosol during the summer in the eastern Mediterranean, Atmos. Chem. Phys., 15, 11355-11371, https://doi.org/10.5194/acp-15-11355-2015, 2015.

Kubelova, L., Vodicka, P., Schwarz, J., Cusack, M., Makes, O., Ondracek, J., and Zdimal, V.: A study of summer and winter highly time-resolved submicron aerosol composition measured at a suburban site in Prague, Atmos Environ, 118, 45-57, 10.1016/j.atmosenv.2015.07.030, 2015.

Lanz, V. A., Prévôt, A. S. H., Alfarra, M. R., Weimer, S., Mohr, C., DeCarlo, P. F., Gianini, M. F. D., Hueglin, C., Schneider, J., Favez, O., D'Anna, B., George, C., and Baltensperger, U.: Characterization of aerosol chemical composition with aerosol mass spectrometry in Central Europe: an overview, Atmos. Chem. Phys., 10, 10453-10471, https://doi.org/10.5194/acp-1010453-2010, 2010.

Li, Y. J., Lee, B. P., Su, L., Fung, J. C. H., and Chan, C. K.: Seasonal characteristics of fine particulate matter (PM) based on high-resolution time-of-flight aerosol mass spectrometric (HR-ToF-AMS) measurements at the HKUST Supersite in Hong Kong, Atmos. Chem. Phys., 15, 37-53, https://doi.org/10.5194/acp-15-37-2015, 2015.

Miyakawa, T., Takegawa, N., and Kondo, Y.: Photochemical evolution of submicron aerosol chemical composition in the Tokyo megacity region in summer, J Geophys Res-Atmos, 113, Artn D14304 10.1029/2007jd009493, 2008.

Park, J., Lee, S., Kang, M., Cho, H. J., Lee, K., and Park, K.: Seasonal characteristics of submicrometer organic aerosols in urban Gwangju, Korea using an aerosol mass spectrometer, Atmos Environ, 80, 445-454, 10.1016/j.atmosenv.2013.08.013, 2013.

Poulain, L., Spindler, G., Birmili, W., Plass-Dülmer, C., Wiedensohler, A., and Herrmann, H.: Seasonal and diurnal variations of particulate nitrate and organic matter at the IfT research station Melpitz, Atmos. Chem. Phys., 11, 12579-12599, https://doi.org/10.5194/acp-1112579-2011, 2011.

Rinaldi, M., Gilardoni, S., Paglione, M., Sandrini, S., Fuzzi, S., Massoli, P., Bonasoni, P., Cristofanelli, P., Marinoni, A., Poluzzi, V., and Decesari, S.: Organic aerosol evolution and 
transport observed at Mt. Cimone (2165 m a.s.1.), Italy, during the PEGASOS campaign, Atmos. Chem. Phys., 15, 11327-11340, https://doi.org/10.5194/acp-15-11327-2015, 2015.

Schurman, M. I., Lee, T., Sun, Y., Schichtel, B. A., Kreidenweis, S. M., and Collett Jr., J. L.: Investigating types and sources of organic aerosol in Rocky Mountain National Park using aerosol mass spectrometry, Atmos. Chem. Phys., 15, 737-752, https://doi.org/10.5194/acp15-737-2015, 2015.

Setyan, A., Zhang, Q., Merkel, M., Knighton, W. B., Sun, Y., Song, C., Shilling, J. E., Onasch, T. B., Herndon, S. C., Worsnop, D. R., Fast, J. D., Zaveri, R. A., Berg, L. K., Wiedensohler, A., Flowers, B. A., Dubey, M. K., and Subramanian, R.: Characterization of submicron particles influenced by mixed biogenic and anthropogenic emissions using high-resolution aerosol mass spectrometry: results from CARES, Atmos Chem Phys, 12, 8131-8156, 10.5194/acp12-8131-2012, 2012.

Sun, J. Y., Zhang, Q., Canagaratna, M. R., Zhang, Y. M., Ng, N. L., Sun, Y. L., Jayne, J. T., Zhang, X. C., Zhang, X. Y., and Worsnop, D. R.: Highly time- and size-resolved characterization of submicron aerosol particles in Beijing using an Aerodyne Aerosol Mass Spectrometer, Atmos Environ, 44, 131-140, 10.1016/j.atmosenv.2009.03.020, 2010.

Sun, Y.-L., Zhang, Q., Schwab, J. J., Demerjian, K. L., Chen, W.-N., Bae, M.-S., Hung, H.-M., Hogrefe, O., Frank, B., Rattigan, O. V., and Lin, Y.-C.: Characterization of the sources and processes of organic and inorganic aerosols in New York city with a high-resolution time-offlight aerosol mass spectrometer, Atmos. Chem. Phys., 11, 1581-1602, https://doi.org/10.5194/acp-11-1581-2011, 2011.

Sun, Y. L., Wang, Z. F., Dong, H. B., Yang, T., Li, J., Pan, X. L., Chen, P., and Jayne, J. T.: Characterization of summer organic and inorganic aerosols in Beijing, China with an Aerosol Chemical Speciation Monitor, Atmos Environ, 51, 250-259, 10.1016/j.atmosenv.2012.01.013, 2012.

Sun, Y. L., Jiang, Q., Xu, Y. S., Ma, Y., Zhang, Y. J., Liu, X. G., Li, W. J., Wang, F., Li, J., Wang, P. C., and Li, Z. Q.: Aerosol characterization over the North China Plain: Haze life cycle and biomass burning impacts in summer, J Geophys Res-Atmos, 121, 2508-2521, 10.1002/2015JD024261, 2016.

Takegawa, N., Miyakawa, T., Kondo, Y., Jimenez, J. L., Zhang, Q., Worsnop, D. R., and Fukuda, M.: Seasonal and diurnal variations of submicron organic aerosol in Tokyo observed using the Aerodyne aerosol mass spectrometer, J Geophys Res-Atmos, 111, Artn D11206 10.1029/2005jd006515, 2006.

Wang, Q. Q., Zhao, J., Du, W., Ana, G. S., Wang, Z. Z., Sun, L., Wang, Y. Y., Zhang, F., Li, Z. Q., Ye, X. N., and Sun, Y. L.: Characterization of submicron aerosols at a suburban site in central China, Atmos Environ, 131, 115-123, 10.1016/j.atmosenv.2016.01.054, 2016.

Xiao, R., Takegawa, N., Zheng, M., Kondo, Y., Miyazaki, Y., Miyakawa, T., Hu, M., Shao, M., Zeng, L., Gong, Y., Lu, K., Deng, Z., Zhao, Y., and Zhang, Y. H.: Characterization and source apportionment of submicron aerosol with aerosol mass spectrometer during the PRIDE-PRD 2006 campaign, Atmos. Chem. Phys., 11, 6911-6929, https://doi.org/10.5194/acp-11-69112011, 2011.

Xing, J. H., Takahashi, K., Yabushita, A., Kinugawa, T., Nakayama, T., Matsumi, Y., Tonokura, K., Takami, A., Imamura, T., Sato, K., Kawasaki, M., Hikida, T., and Shimono, A.: Characterization of Aerosol Particles in the Tokyo Metropolitan Area using Two Different Particle Mass Spectrometers, Aerosol Sci Tech, 45, 315-326, 10.1080/02786826.2010.533720, 2011. 
Xu, L., Suresh, S., Guo, H., Weber, R. J., and Ng, N. L.: Aerosol characterization over the southeastern United States using high-resolution aerosol mass spectrometry: spatial and seasonal variation of aerosol composition and sources with a focus on organic nitrates, Atmos. Chem. Phys., 15, 7307-7336, https://doi.org/10.5194/acp-15-7307-2015, 2015.

Zhang, Y. J., Tang, L. L., Wang, Z., Yu, H. X., Sun, Y. L., Liu, D., Qin, W., Canonaco, F., Prevot, A. S. H., Zhang, H. L., and Zhou, H. C.: Insights into characteristics, sources, and evolution of submicron aerosols during harvest seasons in the Yangtze River delta region, China, Atmos Chem Phys, 15, 1331-1349, 10.5194/acp-15-1331-2015, 2015.

Zhou, S., Collier, S., Xu, J. Z., Mei, F., Wang, J., Lee, Y. N., Sedlacek, A. J., Springston, S. R., Sun, Y. L., and Zhang, Q.: Influences of upwind emission sources and atmospheric processing on aerosol chemistry and properties at a rural location in the Northeastern US, J Geophys Res-Atmos, 121, 6049-6065, 10.1002/2015JD024568, 2016. 